\title{
Volatility and the cross-section of real estate equity returns during Covid-19
}

Stanimira M ilcheva*

First Draft: May 12, 2020

This draft: August 17, 2020

\begin{abstract}
This paper uses the global systemic shock associated with the outbreak of the novel coronavirus Covid19 to assess the risk-return relationship in the cross-section of real estate equities internationally. I construct a global Covid-19 risk factor to capture the risk exposure of individual stocks to the pandemic. The paper also assesses the low-risk effect puzzle in real estate stocks. I find that the average firm sensitivity to the Covid-19 risk factor increases from close to zero prior to the pandemic to 0.6 during the pandemic with large variations across countries and sectors. Fama-MacBeth regressions reveal evidence for a low-risk effect - both through market and Covid-19 risks - which is not be associated with behavioral biases but rather with financial constraints. Consistent with recent research, the findings in this paper suggest that investors perceive the shock caused by the Covid-19 to be amplified by financial channels.
\end{abstract}

Keywords: Low-risk effect, coronavirus, Covid-19 risk factor, pandemic, financial constraints, behavioural effects, factor model, Fama M acBeth, REITs, systemic risk.

JEL Classification: G1, G14, I1, D84, R30.

\footnotetext{
* Bartlett Faculty, University College London, 1-19 Torrington Place, London WC1E 7HB, UK; email: s.milcheva@ucl.ac.uk.
} 


\section{Introduction}

The novel coronavirus Covid-19 emerged in China in December 2019 and was declared a global pandemic on $11^{\text {th }} \mathrm{M}$ arch 2020 by the World Health Organisation (WHO). The virus is highly infectious ${ }^{2}$ but with a lower mortality rate than other coronaviruses such as SARS and MERS. ${ }^{3}$ Given it is a new virus, there has not been a vaccine or a treatment for it which to prevent it from spreading. Given the severity of the virus, many countries have taken the decision to go into a "lockdown" in the early stages of the outbreak. China was the first country to impose a lockdown (January 2020) and the first one to open back its economy ( $M$ arch 2020) while a large number of other countries entered into some form of lockdown about two months later (March 2020). ${ }^{4}$ During the first couple of months of the coronavirus outbreak, a number of Asian countries such as Singapore, South Korea, Taiwan did not impose a lockdown and employed rigorous testing and tracking of the infected cases. Their response was different from those of most other countries due to their previous experience with similar coronavirus outbreaks. Covid-19 has led to the shut-down of entire economies and the paralysis of air traffic around the world. Households in more than $40 \%$ of the countries around the world were asked to stay at home for a large part of the first half of 2020 to prevent the spread of the virus. Only essential businesses were operating at the peak of the virus outbreak. Supply chains for basic products, food, healthcare consumables, personal protective equipment such as masks have heavily been affected as a result.

The outbreak of Covid-19 has caught most countries without previous experience with similar coronaviruses by surprise and some were slower to react than others. The economic implications of Covid-19 are expected to be worse than that of the Global Financial Crisis (GFC). OECD (2020) projections for Gross Domestic Product (GDP) expect a decline in World GDP by up to $7.6 \%$ with the worst hit counties being Spain, France, Italy and the UK where GDP is expected to go down by up to $14 \%$ in the case of a second Covid-19 wave. However, before any economic data became available, stock markets were the first to respond to the systemic shock associated with Covid-19 as asset prices of frequently traded assets contain information about expectations of investors about future cash flows and risks (Harvey, 1989). That response is going to be analysed here in more detail.

This paper adds to the rapidly emerging literature on the effects of Covid-19 on stock markets by (1) constructing a Covid-19 Risk Factor linked to daily changes in confirmed global coronavirus infections.

\footnotetext{
${ }^{2}$ The anticipated $\mathrm{R}$, or infection rate, during the peak of the virus is between 3 and 4 and varies by time and location.

${ }^{3}$ However, the mortality rate is expected to be about ten times higher than that of a normal flu.

${ }^{4}$ The US has followed with a large number of states adopting some form of a lockdown in March and April 2020.
} 
The paper looks at how Covid-19 risk exposures affect the cross-section of returns in addition to other systematic and idiosyncratic risks. (3) 2) I also examine the presence of a low-risk effect for real estate companies. Returns are regressed on various measures of risks and other controls in a Fama M acBeth setting in order to assess the cross-sectional link between risk and return. (4) The study looks at secotr and country level differences in performance as a result of the pandemic.

While some information about Covid-19 emerged on the last day of 2019 and throughout January 2020, it is not until late February 2020 when stock markets started to factor in potential negative effects associated with the novel coronavirus. 21 February 2020 marks the day when stocks internationally started a series of declines factoring in information about Covid-19 as information emerged on multiple infected cases outside China. Around that time, South Korea and Iran reported a large surge in infections. Up until that point, experts have assumed that the virus could be contained within China. Similarly, investors would have assumed that only companies with links to China and heavily relying on US supply chains would be negatively affected. However, by the end of February, fears about a global outbreak started to materialise. Italy became the first European country to be seriously affected, with the coronavirus spreading fast out of Italy into other European countries. Within a matter of days, stock markets have fallen by up to $40 \%$ from their values in January 2020 .

To analyse the effect of the pandemic on the economy, early studies have been conducted looking at the stock markets, since they are fastest to response and provide reliable economic data in the early stages of the pandemic. Gormsen and Koijen (2020) show that the Covid-19 outbreak has very similar effects on the stock market response to the effects from the Global Financial Crisis (GFC) in 2008, with sharp declines in stock markets. Alfaro et al. (2020) conduct an event study linking unexpected changes in the trajectory of Covid-19 and SARS to changes in aggregate and firm-level returns by looking at model predictions of anticipated infections. Those models have been used in the early stages of the pandemic and have attracted a lot of general public attention due to very bleak infection forecasts. Alfaro et al. (2020) find large variation in responses across US companies with responses being stronger for more leveraged firms. They suggest that "debt-laden and capital-intensive firms are less likely to be able to reduce costs as revenues decline". Ramelli and Wagner (2020) look into the drivers of firm value linked to firm characteristics following the pandemic. They assess how the exposure of US firms to China trade, their debt and cash holdings affect firm value. The authors find that returns are lower for firms with high trade exposure with China in the early stages of the pandemic but higher since February when the situation in China starts to improve. Furthermore, similar to Alfaro et al. (2020), Ramelli and Wagner (2020) show that more leveraged firms suffer severely during the "Fever" period of the pandemic - from 24 February until $20 \mathrm{M}$ arch 2020. Similarly, Fahlenbrach et al. (2020) show that firms with less financial flexibility experience lower equity returns 
up until the announcement of monetary easing by the Federal Reserve on $23 \mathrm{March} 2020$. Ding et al. (2020) assess the relationship between corporate characteristics and stock price reactions to Covid19 cases. They also report that firms with strong fundamentals report less strong declines in their stocks. In particular, firms with less debt, more cash and larger profits, in addition to other factors, are behind these reactions. Ling et al. (2020) are the first to look at the effect of Covid-19 on commercial real estate prices. The authors construct a firm-level measure of Covid-19 exposure by using the location of the properties of the real estate companies and linking those with county-level reported coronavirus cases. Regional exposure to Covid-19 based on the property holdings of a firm leads to significant declines in its return on average. However, the effect largely varies by property type. Ling et al. (2020) show that healthcare and technology real estate investment trusts (REITs) observe positive correlation with the firm's exposure to Covid-19. Retail, office and residential REITs have a negative relationship instead.

In this paper, I build on above research and use the period around the outbreak of Covid-19 to assess the effects on the stock markets, focussing on analysing the slope of the security market line (SML) for real estate equities. The SML describes the relationship between returns and risks (betas). Classic investment theories suggest that high returns are associated with high risk and low returns with low risk, hence the SML should be upward sloping. However, a number of studies (Black, 1972; Frazzini and Pedersen (2011, 2014); Asness et al., 2020) find evidence of a so-called 'low-risk effect' in which assets with high risk are associated with positive returns. One explanation for the low-risk effect is associated with leverage constraints (Black, 1972; Frazzini and Pedersen $(2011,2014)$ ). This includes liquidity considerations (M alkhozov et al., 2016) and benchmark constraints (Brennan, 1993; Baker et al., 2011). The other most dominant explanation, which is associated with idiosyncratic risk rather than systematic risk, is linked to behavioural biases. Ang et al. $(2006,2009)$ demonstrate that stocks with low idiosyncratic volatility are associated with high returns. Behavioral biases may thus be associated with this positive relationship. Asness et al. (2020) claim that such biases can be captured by investor's preference for lottery-like returns (Barberis and Huang, 2008; Brunnermeier et al., 2007). The authors demonstrate that both, leverage constraints associated with margin debt, and behavioural drivers, associated with sentiment, explain the positive relationship of systematic and idiosyncratic volatilities with returns.

In general, real estate companies are characterized by low exposure to market shocks. That can be partially due to the dominance of idiosyncratic risks and the low correlation of real estate stocks with overall equity indices during normal times. During Covid-19, real estate is among the industries hardest hit as countries around the world have entered in lockdowns and shut most service-related industries. The worst affected sectors are leisure such as retail shops, cinemas, pubs, restaurants, 
hotels, casinos, etc. Other real estate sectors, such as industrial or healthcare (senior homes) may be less affected in turn. Having a close look at an industry that is directly affected by the coronavirus outbreak sets the low boundary of the Covid-19 effect on stock valuations as investors would be fast to adjust their expectations for sectors where cash flows and risks are easily identifiable. The majority of those companies derive more than $80 \%$ of their revenues from renting out real estate space and the direct effect would be a rent reduction and lower net operating income. Thus, when businesses shut down as a result of lockdown policies, real estate revenues from rents decline in the absence of government subsidies. Investors may also change their assessment of the discount rates if they think that the cash flows of some companies are associated with considerably more risk as a result of the pandemic.

The study finds that the co-movement of real estate firms with the market increases dramatically during the pandemic suggesting that during volatile periods, as was the case during the GFC, real estate stocks strongly follow the general stock market volatility. The effect of Covid-19 is associated with steep declines in average daily returns of real estate returns and a steep increase in market and idiosyncratic risks. Furthermore, the average firm sensitivity to the Covid-19 risk factor increases from close to zero prior to the pandemic to 0.6 during the pandemic. However, there are huge differences across sectors and firm locations. Retail has the highest sensitivity to Covid-19, 1.2, whereas health care has the lowest sensitivity, 0.25 . M oreover, the results from the Fama-M acBeth regressions point towards a significant low-risk effect - stemming from market and Covid-19 risks which is not explained by behavioural biases. Firms with high exposure to Covid-19 have been associated with steep declines in average daily returns. This effect is mostly explained by leverage constraints. Firms with the same Covid-19 exposure would have lower returns if their leverage is higher. Lastly, the effect of the pandemic on sectors has been associated with widening the gap between the performance across sectors. In line with the existing research on the effects of Covid-19 on stock markets, the findings in this paper suggest that investors perceived the shock caused by Covid-19 to be amplified by financial channels.

\section{Relevant literature}

This paper is most closely related to the literature looking at idiosyncratic volatility and the crosssection of equity returns. The seminal work of Ang et al. (2009) is one of the first ones to document this relationship. The authors show that idiosyncratic volatility can explain the cross-sectional variation in returns. Counter to the common intuition and classic investment models, the relationship is found to be negative, suggesting that investors demand stocks with high idiosyncratic risk. They do 
not explain the mechanisms behind it but conclude that the effect is highly significant. A host of papers follow on to explore various channels explaining this puzzle.

Several reasons for the failure of the risk-return trade-off implied by the Capital Asset Pricing Theory have been discussed in the literature. Among those are channels associated with (1) leverage constraints (Asness et al., 2012; Black, 1972; Frazzini and Pedersen, 2014, Li, 2016), (2) benchmarked institutional investors (Baker et al., 2011; Brennan, 1993), (3) money illusion (Modigliani and Cohn, 1979; Cohen et al., 2005), (4) disagreement among investors (see, e.g., Hong and Sraer, 2011; Bali et al. (2018)), (5) market-wide sentiment-induced mispricing (see, e.g., Shen and Yu, 2012; Asness et al., 2020). A recent study by Bali et al. (2018) argues that the low-risk effect may be due to divergence of opinion among investors. Investor disagreements about the firm value are caused by unusual firmlevel news flows. More pessimistic investors may face restrictions on short selling and hence be prevented from expressing their views and those may not be reflected in the price. Therefore, the negative relationship between idiosyncratic volatility and cross-sectional returns reflects optimistic views directly following the news flows. Li (2016) show that high macro-beta stocks yield low returns as compared to low macro-beta stocks as a result of macro disagreements. Rachwalski and Wen (2016) show that stocks with high idiosyncratic volatility earn low subsequent returns for a few months which they explain by temporary underreaction to idiosyncratic risk innovations.

Wang et al. (2017) also test the negative risk-return relationship showing that it holds among firms in which investors face prior losses. It does not hold across firms that experience gains. An explanation for that might be reference-dependent preferences of investors. Another set of studies (Bali et al., 2011; Barberis and Huang, 2008; Bali et al., 2014) consider that investors who prefer returns with high skewness and those firms tend to be high-risk firms and overpriced, hence earning low abnormal returns. Asness et al. (2020) investigate the low-risk effect stipulated in Black et al. (1972) when assets with low risk are associated with high alphas. One reason for that could be leverage constraints and hence risk should be measured using beta. Another could be associated with behavioural effects and hence risk should be measured using the volatility of idiosyncratic risk. The authors introduce two new factors: betting against correlation (BAC) factor for the market risk and a scaled maximum return (SMAX) factor for the idiosyncratic risk in order to disentangle the drivers of the low-risk effect. They find that both factors play a role in explaining the low-risk effect consistent with leverage and lottery theories of this relationship.

I would add to the above literature by examining those relationships in the context of an unexpected global systemic shock associated with Covid-19. 


\section{Data}

\section{Covid-19 Risk Factor}

In order to account for risks associated with firm's exposure to Covid-19, I construct a Covid-19 risk factor. The construction of the factor follows the standard approach of Fama and French by grouping companies into the top and bottom quartiles of a distribution and creating a long-short portfolio. In this case, I sort firms based on their exposure to Covid-19. To construct the factor, there are a number of steps.

First, in order to sort firms on their exposure to Covid-19, I first need to quantify their exposure to Covid-19 risks. For that, I estimate a factor model of daily stock returns for each company one by one for the early Covid-19 period - from 21 February until 21 April 2020. I regress the returns of each firm on a number of factors, described below, and on the daily log-change in global Covid-19 cases. More than $80 \%$ of the companies respond negatively to increases in daily coronavirus infections worldwide. This means that a firm having a large negative coefficient would be associated with high exposure or sensitivity to Covid-19. In the general case, when the coefficient takes positive values too, a firm would have high exposure if the coefficient is further away from zero, and low exposure if the coefficient is closer to zero.

In the next step, the coefficients associated with the change in daily global infections are then used to sort stocks into two portfolios - a high exposure to Covid-19 portfolio and a low exposure to Covid-19 portfolio. The former consists of an equally-weighted average of the top $20^{\text {th }}$ quantile of stocks sorted on absolute value of their exposure to Covid-19. The latter consists of the bottom $20^{\text {th }}$ quantile of the stocks. The Covid-19 Risk Factor is a portfolio long on the high-exposure portfolio and short on the low-exposure portfolio. Stocks which have high sensitivity to this Covid-19 Risk Factor (i.e. high Covid19 beta) would be those that are responding more strongly to the pandemic.

Figure 1 shows the returns of two Covid-19 risk factors - a risk factor constructed using stock market and real estate indices, the baseline specification, described below, and a risk factor constructed using the three Fama and French (FF) factors instead. The correlation between the risk factors is high at $68 \%$. In the remainder of the paper I will only use the baseline risk factor and will report results for the latter factor in the Robustness section. Firms with high and low sensitivity to the pandemic did not show large differences in returns prior to the virus outbreak up until late February when the virus started to be registered in Europe. The divergence in performance became substantial during $\mathrm{M}$ arch 2020 when the seriousness of Covid-19 and the implications on the economy started to become clear. The volatility in the factor substantially rose during that period. For most of it, returns of the Covid-19 
Risk Factor were negative, suggesting that stocks with high exposure to the pandemic substantially underperform stocks with low exposure to it. The (baseline) factor displayed a daily return of as low as $-8 \%$ on $23 \mathrm{M}$ arch 2020 , the last day of dramatic daily drops in the stock markets, and the day before a ground-breaking package of Federal Reserve stimuli was announced in the US.

\section{Figure 1: Daily returns of the Covid-19 Risk Factor}

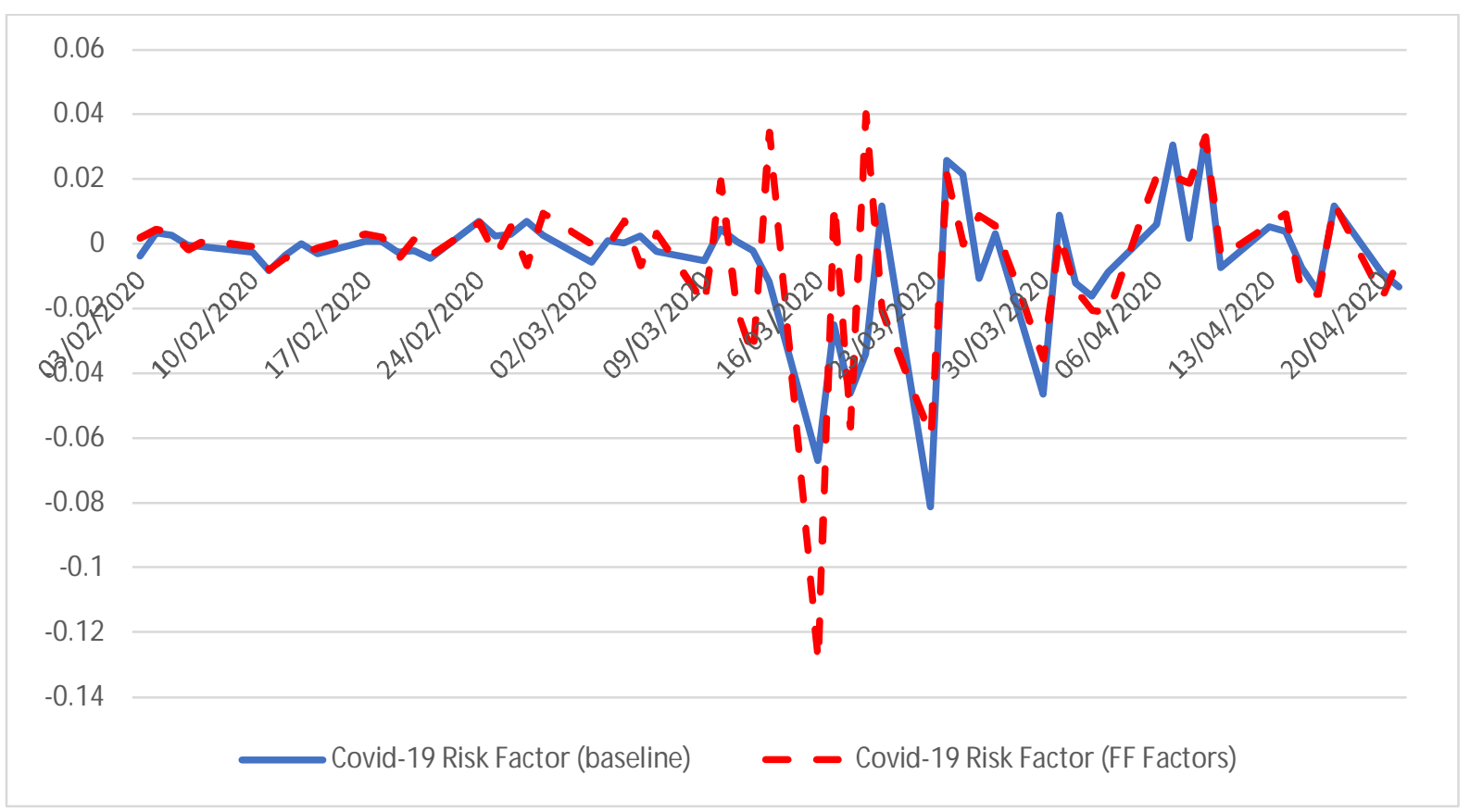

Note: The Covid-19 Risk Factor represents a portfolio long on stocks with high Covid-19 exposure and short on stocks with low Covid-19 exposure. The blue continuous line is the baseline risk factor used in all remaining regressions. The red dashed line is a risk factor calculated using the three $\mathrm{FF}$ factors instead.

The Covid-19 Risk Factor is used alongside a market factor and a real estate factor to estimate factor models for each stock and each period. ${ }^{5}$ The expectation is that the majority of the companies will have a positive Covid-19 beta. The higher the beta, the higher the exposure to Covid-19 risks.

\section{Covid-19 cases}

In order to calculate the Covid-19 risk factor, I use information about confirmed infections. The daily Covid-19 confirmed cases data is collated by John Hopkins University and accounts for cases that have

\footnotetext{
${ }^{5}$ We also use the Fama and French (FF) factors for robustness purposes. The first draft of the paper was written prior to the availability of the most up-to-date FF factors and hence, I used alternative factors. The results are reported in the Robustness section.
} 
been tested for coronavirus and confirmed to have the virus. The number of cases does not include all people who may have contracted the virus. In most countries, only people who end up in more serious conditions only get tested or people who are treated in hospitals. Each country has its own approach to testing with countries like Germany and the Asian countries in our sample conducting much more tests than others, like the UK or the US. This is due to lack of testing kits or testing capabilities. Despite the incomplete way of capturing the risk of Covid-19, in the early days of the pandemic, the number of confirmed cases was seen as the main source of information about the seriousness of Covid-19 and about how quickly it spreads which will determine whether or when a country goes in a lockdown. Therefore, increases to the number of confirmed Covid-19 cases could be seen as an indicator of Covid-19 related risks. Those risks are systemic in nature as the virus is highly infectious and quickly spreads across countries and communities. To account for the global systemic nature of the risk, I aggregate the number of cases across all countries with available data. As we often associate systemic risks with "contagion", in the case of Covid-19, the contagion is meant literarily as evidenced by the fast increase in infected people around the world. Covid-19 risks can therefore be linked to the contagion of the virus.

\section{Other factors}

To proxy for the global market factor, we use the M SCI World index; the global real estate factor is captured by the FTSE EPRA/NAREIT global index. We also use the Fama and French (FF) three factors for robustness purposes.

Figure 2 plots the cumulative daily changes of MSCI World, S\&P 500 and STOXX 600 between 23 January 2020 and 21 April 2020. January $23^{\text {rd }}$ is when a lockdown of Wuhan, China, was announced and when the news about a new virus started making headlines. At that stage the World Health Organisation (WHO) did not yet classified Covid-19 as a pandemic and the rest of the world assumed that the virus will be contained within China. Most countries continued with business as usual although some supply chains started to be affected following lockdown policies across the whole of China a few days later.

I compare the MSCl World with other two stock market indices commonly used as benchmarks STOXX 600 and the S\&P 500. All indices follow a similar pattern. Prior to 24 March 2020, the relationship between the number of confirmed Covid-19 cases/deaths and stock market returns is negative (see Figure 2). On 24 March 2020, the stock markets in the US had their "whatever it takes" moment with the Federal Reserve (Fed) announcing that it will do whatever it takes to preserve 
financial stability. The Fed announced its quantitative easing (QE) program buying securities including the likes of corporate bonds and agency commercial mortgage backed securities (CM BS). Parallel to that, the US and many other countries announced large fiscal support packages to help employees and employers, small and large businesses, etc.

Once the monetary and fiscal support mechanisms have been announced (mostly in the US), the equity markets start to gradually recover the lost value (see Figure 2). This is despite a continuation of the growth in Covid-19 cases and deaths as seen in Figure 2.

\section{Figure 2: Cumulative daily changes of global stock market returns and Covid-19 cases and deaths}

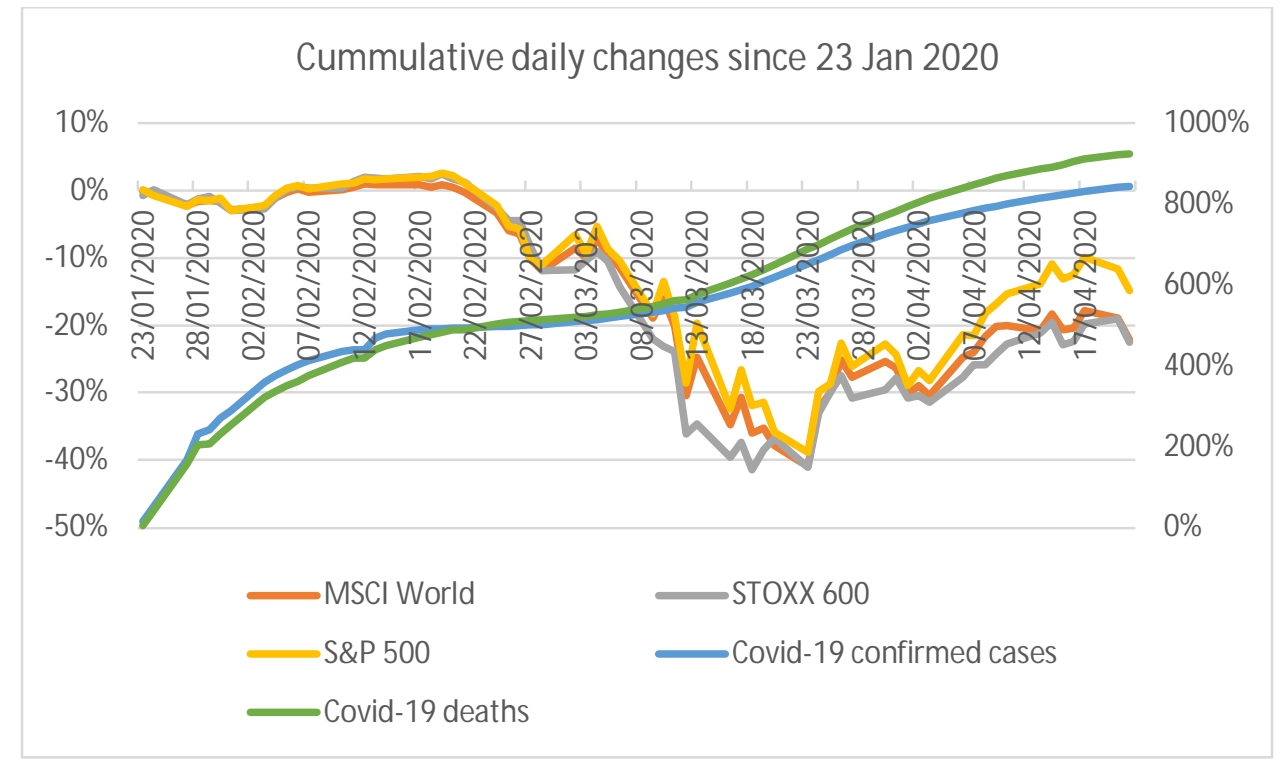

Note: Right axis is Covid-19 deaths and confirmed cases cumulative growth rate since 23 January 2020. Left axis are the stock market index cumulative daily returns since 23 January 2020.

Table 1 shows that the correlation of various factors with the Covid-19 risk factor. The correlation with the selected stock market indices is positive prior to the pandemic. It turns negative with the virus outbreak. We also see that the correlation is stronger before the pandemic than during its initial phase. Prior to the pandemic, the correlation with the Covid-19 risk factor ranges between $26-39 \%$. During the initial outbreak period, the correlation is between $-4.3 \%$ and $-9.5 \%$. This suggests that while firms with the highest Covid-19 exposure prior to the pandemic had some, although not huge, similarity to the overall market, they drifted apart once the virus broke out. The Covid-19 risk factor thus captures new information, not linked to the fundamentals of the stock markets. This is confirmed by the high correlation of the Covid-19 risk factor with the Covid-19 daily growth rate in confirmed 
cases or deaths, 33\% and $40 \%$ respectively. The Covid-19 risk factor captures risks associated with a contagion effect and a widespread systemic effect of the virus.

Table 1: Correlation of factors with the Covid-19 Risk Factor before and during the pandemic outbreak $^{6}$

\begin{tabular}{|l|l|l|l|l|l|l|}
\hline & $\begin{array}{l}\text { MSCI } \\
\text { World }\end{array}$ & $\begin{array}{l}\text { STOXX } \\
\mathbf{6 0 0}\end{array}$ & S\&P 500 & $\begin{array}{l}\text { FTSE } \\
\text { EPRA/ NAREIT } \\
\text { Global }\end{array}$ & $\begin{array}{l}\text { Covid-19 } \\
\text { daily } \\
\text { cases } \\
\text { growth }\end{array}$ & $\begin{array}{l}\text { Covid-19 } \\
\text { daily } \\
\text { deaths } \\
\text { growth }\end{array}$ \\
\hline $\begin{array}{l}\text { Covid-19 Risk Factor, } \\
\text { Pre-Covid-19 period }\end{array}$ & $31 \%$ & $31 \%$ & $26 \%$ & $39 \%$ & NA & NA \\
\hline $\begin{array}{l}\text { Covid-19 Risk Factor, } \\
\text { Covid-19 period }\end{array}$ & $-6.3 \%$ & $-7 \%$ & $-4.3 \%$ & $-9.5 \%$ & $33 \%$ & $40 \%$ \\
\hline
\end{tabular}

\section{Company data}

The initial sample contains 461 real estate companies across seven countries - China, Hong Kong, Japan, Singapore, Sweden and the US. However, the regression models contain a reduced sample of 390 companies as not every company reports all the firm-level accounting data we need for the Fama MacBeth regressions. The US companies represent about one half of the sample. The data comes from SNL Financial. Figure 3 shows the cross-sectional return distribution of the average daily returns in two periods - pre Covid-19 and early Covid-19. The dispersion in returns across companies is much smaller before the outbreak than in the early stages of the outbreak and daily returns are mostly close to zero prior to the pandemic. During the early stages of pandemic, the average daily return is around $-1 \%$. The dispersion has increased three- to four-fold. The majority of the returns are below zero. The left tail of the distribution has shifted considerably further to the left with much lower negative returns in the $25^{\text {th }}$ quantile, below $-2.5 \%$.

\section{Figure 3: Distribution of daily returns in the cross-section}

\footnotetext{
${ }^{6}$ The correlation prior to the pandemic is not reported as data for the confirmed cases and deaths does not exist. However, the correlation in the pre-Covid-19 period is available for the factors used in the model.
} 


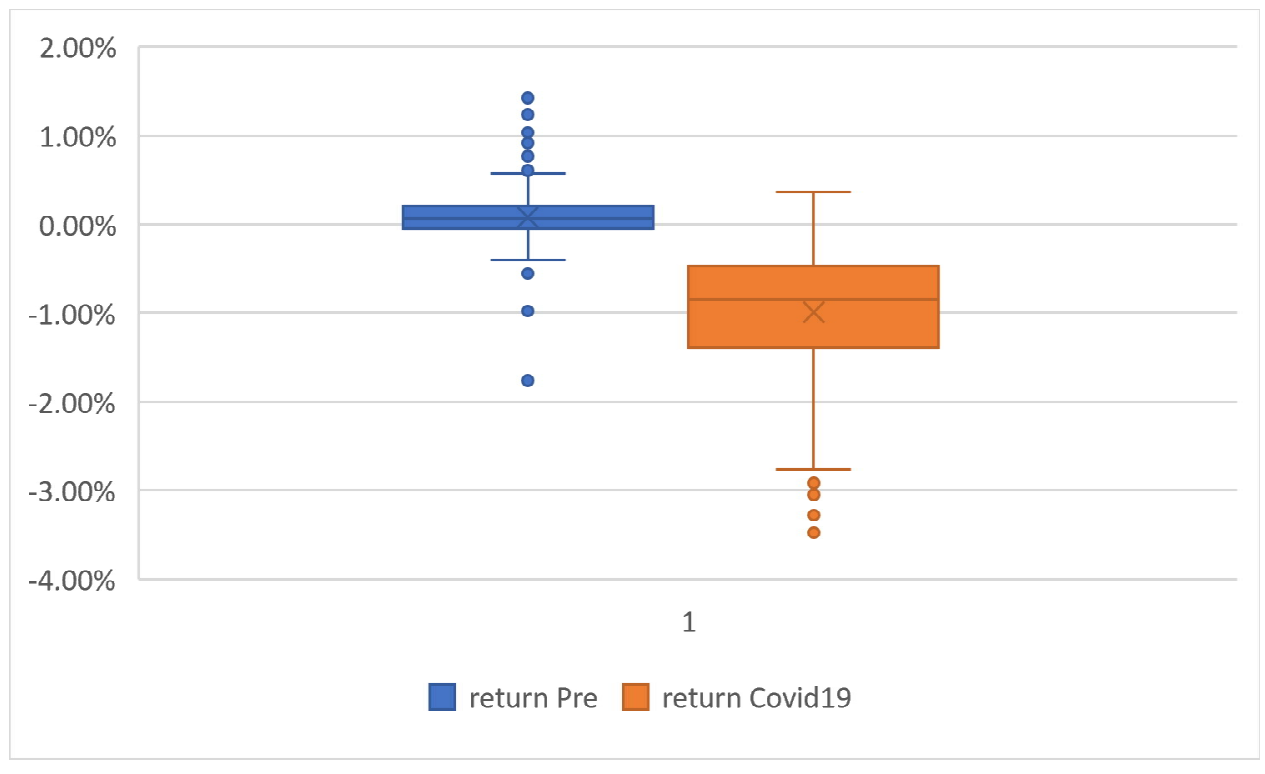

Note: The box-and-whisker plot shows the minimum, first quartile, median, third quartile, and maximum of our data. The data contains 461 listed real estate companies in China, Hong Kong, Japan, Singapore, Sweden, Taiwan, US. The pre-Covid-19 period is from 21 November 2019 until 20 February 2020. The Covid-19 period is from 21 February 2020 until 21 April 2020.

Table 2 shoes descriptive statistics of the daily average returns by country and by period. A total of 213 US listed real estate companies enter the sample. This covers most of the universe of listed real estate companies in the US as of April 2020. The second largest set of countries are headquartered in Japan - a total of 74 companies. For Sweden there are 14 companies. Swedish companies have the highest average daily return of $0.28 \%$ prior to Covid- 19 . The lowest average daily return is registered in Hong Kong, $-0.01 \%$, pre-Covid-19. During Covid-19, the lowest return is observed in Sweden ($1.28 \%$ ) closely followed by the US and Japan.

Table 2: Descriptive statistics of listed real estate company daily returns by country and by period

\begin{tabular}{lccccc}
\hline & \multicolumn{5}{c}{ Std. } \\
& Obs & Mean & Dev. & Min & Max \\
\hline \multirow{5}{*}{ China } \\
return Pre & 36 & 0.0005 & 0.0021 & -0.0032 & 0.0049 \\
return Covid-19 & 36 & -0.0039 & 0.0039 & -0.0170 & 0.0036 \\
& \multicolumn{5}{c}{ Hong Kong } \\
return Pre & 66 & -0.0001 & 0.0026 & -0.0055 & 0.0124
\end{tabular}




\begin{tabular}{lccccc} 
return Covid-19 & 66 & $\begin{array}{c}-0.0048 \\
\text { Japan }\end{array}$ & 0.0032 & -0.0123 & 0.0026 \\
return Pre & 74 & 0.0010 & 0.0020 & -0.0048 & 0.0042 \\
return Covid-19 & 74 & -0.0120 & 0.0042 & -0.0201 & -0.0020 \\
& \multicolumn{5}{c}{ Singapore } \\
return Pre & 57 & 0.0010 & 0.0015 & -0.0012 & 0.0061 \\
return Covid-19 & 58 & -0.0068 & 0.0030 & -0.0176 & -0.0003 \\
& & Sweden & & & \\
return Pre & 14 & 0.0028 & 0.0021 & -0.0003 & 0.0058 \\
return Covid-19 & 14 & -0.0128 & 0.0038 & -0.0236 & -0.0081 \\
& & USA & & & \\
return Pre & 213 & 0.0008 & 0.0030 & -0.0176 & 0.0142 \\
return Covid-19 & 213 & -0.0125 & 0.0086 & -0.0348 & 0.0031
\end{tabular}

Note: The pre-Covid-19 period ranges from 20 December 2019 until 21 February 2020. The Covid-19 period ranges from 21 February 2020 until 21 April 2020.

Table 3 shows the average daily return of real estate firms for two sub periods and across property sectors. The classification in the property sectors indicated in Table 3 comes from SNL Financial. The majority of the real estate companies have diversified sector portfolio - 186 of the firms in our sample. The second largest group is retail with 53 companies - split between shopping centers, regional malls and other retail. The third and fourth largest sectors are hotel and office with 47 and 46 firms respectively. We can see that similar to the splits by country, the returns by sector are much lower during the Covid-19 period. The lowest daily average return is observed for real estate companies specialising on shopping centers (-1.64\%), followed tightly by hotels (-1.6\%) and regional malls (-1.5\%). Those are the sectors which also have the lowest average returns prior to the outbreak. The outbreak did not create new losers but exacerbated the problems in already struggling sectors. The highest returns during Covid-19 are observed for companies specialising in self-storage, industrial or speciality real estate. Prior to the pandemic, casinos have had by far the highest average daily return, followed by industrial, manufactured homes and health care. The biggest changes in performance between the two periods are registered for hotels, followed by other retail, diversified real estate and shopping centers. The smallest change of returns during Covid-19 is observed for industrial.

Table 3: Descriptive statistics of listed real estate company daily returns by sector and by period 
Return Pre Covid-19

\begin{tabular}{lrrrrr} 
Sector & Obs & Mean & Std. Dev. & Mean & Std. Dev. \\
\hline Casino & 3 & 0.0030 & 0.0007 & -0.0130 & 0.0038 \\
Diversified & 186 & 0.0006 & 0.0022 & -0.0082 & 0.0057 \\
Health Care & 24 & 0.0020 & 0.0015 & -0.0121 & 0.0077 \\
Hotel & 47 & -0.0008 & 0.0026 & -0.0159 & 0.0089 \\
Industrial & 32 & 0.0025 & 0.0019 & -0.0062 & 0.0035 \\
Manufactured homes & 3 & 0.0022 & 0.0013 & -0.0071 & 0.0010 \\
Multifamily & 25 & 0.0012 & 0.0015 & -0.0083 & 0.0039 \\
Office & 46 & 0.0014 & 0.0015 & -0.0101 & 0.0052 \\
Shopping Center & 23 & -0.0012 & 0.0011 & -0.0164 & 0.0084 \\
Regional Mall & 15 & -0.0015 & 0.0071 & -0.0149 & 0.0105 \\
Other retail & 15 & 0.0009 & 0.0024 & -0.0133 & 0.0089 \\
Self-Storage & 7 & 0.0009 & 0.0008 & -0.0055 & 0.0033 \\
Specialty & 35 & 0.0018 & 0.0027 & -0.0067 & 0.0077
\end{tabular}

Note: The pre-Covid-19 period ranges from 20 December 2019 until 21 February 2020. The Covid-19 period ranges from 21 February 2020 until 21 April 2020.

Table 4 shows the descriptive statistics of the firm-level variables including the average returns in the pre-Covid-19 and the Covid-19 periods. ${ }^{7}$ In total, 390 individual firms are used in the regression analysis. As discussed above, the average cross-sectional daily return prior to the coronavirus outbreak is $0.08 \%$ as compared to $-1 \%$ during the outbreak. This is a drop of more than ten times. More than $95 \%$ of the average daily returns during the pandemic are in negative territory. Total assets average almost $\$ 53$ billion but there is a large variation across firms, from as little as $\$ 111$ million to over $\$ 284$ billion. The average level of debt for 2019 is about $41 \%$ with the $95^{\text {th }}$ percentile of the companies having debt ratios below $67 \%$. These are much lower leverage ratios as compared to pre-GFC period. As a result of the GFC, REITs have undergone substantial deleveraging. The price-to-book (PtB) ratio in 2019 is on average 1.6, meaning that the investors think that the value of REITs should be more than $50 \%$ higher than the reported value of their real estate portfolio. About $5 \%$ of the companies have PtB ratios of as low as 0.38 ; instead, firms in the top $5^{\text {th }}$ percentile have a PtB ratio of more than 3.7. The return on average assets for the sample of companies in 2019 is 3.3\%, however, $5 \%$ of the

\footnotetext{
${ }^{7}$ The financial variables are available in M arch 2020 and refer to the previous financial year, therefore they do not reflect the effect of the pandemic yet.
} 
companies have achieved a return of $8 \%$ or above. In total, $66 \%$ of the sample consists of real estate companies that have the REIT status.

Table 4: Descriptive statistics of the firm-level variables

\begin{tabular}{|c|c|c|c|c|c|}
\hline Variable & Obs & Mean & Std. Dev. & 5th & 95th \\
\hline return Pre-Covid-19 & 390 & 0.0008 & 0.0027 & -0.0027 & 0.0041 \\
\hline return Covid-19 & 390 & -0.0100 & 0.0068 & -0.0232 & -0.0002 \\
\hline Total assets (in mn) & 390 & 52,900 & 183,000 & 111 & 284,000 \\
\hline DtA & 390 & 0.41 & 0.15 & 0.15 & 0.67 \\
\hline PtB & 390 & 1.59 & 1.12 & 0.38 & 3.7 \\
\hline ROAA & 390 & 0.033 & 0.047 & -0.007 & 0.082 \\
\hline REIT dummy & 390 & 0.66 & 0.47 & 0 & 1 \\
\hline
\end{tabular}

Note: DtA stays for the debt-to-assets ratio, PtB stays for the price-to-book ratio, ROAA stays for the return on average assets, REIT dummy takes the value of 1 if the company has a REIT status.

\section{Methodology}

The analysis is conducted in two steps. In step one, I estimate factor models with the Covid-19 Risk Factor for each company one by one for two periods - "Pre Covid-19" and "Covid-19" period respectively. The first period ranges from 21 November 2019 until 20 February 2020. The second period ranges from 21 February until 21 April 2020. For each period, I estimate the following factor model:

$r_{i, t}=\alpha_{i, p}+\beta_{i, f, p} \sum_{f=1}^{N} R_{f, t}+\beta_{i, \text { Covid }, p} R_{\text {Covid }, t}+\varepsilon_{i, t}$

with $r_{i, t}$ the daily return for company $\mathrm{i}$ in day t. $\alpha_{i, p}$ is the non-market return or alpha for company $\mathrm{i}$ in period $p$ with $p=1$ for the pre-Covid- 19 sample and $p=2$ for the Covid- 19 sample. $R_{f, t}$ denotes the $f$ th factor. $R_{\text {Covid,t }}$ denotes the Covid-19 Risk Factor. $\varepsilon_{i, t}$ is the residual of the factor model. $\beta_{i, f, p}$ is fth coefficient, the company beta, for the $n$ factors.

The second step consists in estimating a Fama-M acBeth cross-sectional regression for each of the two periods. The Fama-M acBeth model is estimated as:

$\bar{r}_{i, p}=a * \sigma_{i, p}+b_{f} * \sum_{f=1}^{N} \beta_{i, f, p}+c * \beta_{i, \text { Covid }, p_{p}}+d *$ Controls $_{i}+f *$ Country $_{i}+g *$ Sector $_{i}+$

$\epsilon_{i, t}$

with $\bar{r}_{i, p}$ the average daily return of a company $i$ for one of the two periods ( $p$ ). $\beta_{i, f, p}$ are the explanatory variables which are the risk loadings estimated in Equation (1). $\beta_{i, \text { Covid }, p}$ is the i-the Covid- 
19 beta for period p from Equation (1). Controls $s_{i}$ include company-specific variables which are mostly related to reported financial data such as the market-to-book ratio, the total asset size, debt-to-assets ratio, etc. These variables are reported once a year and would not show variation over time as we only use data from November 2019 until April 2020. We also include country fixed effects and sector fixed effects. Standard errors are clustered by firm. $\sigma_{i, p-1}$ stays for the past idiosyncratic volatility of a firm in $p-1$ or the month prior to the beginning of the respective period $p$. The past idiosyncratic volatility is estimated using the standard deviation of the residual of a standard factor model which has a standard deviation of $\sigma_{i, p}$ for each period. The residuals are a product of the model below:

$r_{i, t}=\gamma_{i, p}++\beta_{i, f, p} \sum_{f=1}^{N} R_{f, t}+$ residual $_{i, t}$

Equation (3) does not include the Covid-19 risk factor even when the residual standard deviation is calculated for the Covid-19 period. As mentioned above, the idiosyncratic risk is estimated for daily returns for the month preceding each period. This is the way past idiosyncratic volatility is estimated in Ang et al. (2009), Bali et al. (2018) and others who look at cross-sectional returns and idiosyncratic volatility shocks.

\section{Results}

\subsection{Factor regressions}

The results from the first step, which is based on Equation (1), are summarised in Table 5. As I regress each firm on the risk factors individually, the coefficients reported in Table 5 show the summary statistics of the estimates across all firms - alpha and beta - for the pre-Covid-19 and early Covid-19 periods. I report the mean, the standard deviation, the $25^{\text {th }}$ and $75^{\text {th }}$ percentile of the distribution. Figure 4 plots the distributions of the coefficients for the two periods.

Table 5: Descriptive statistics of listed real estate company daily returns by period

\begin{tabular}{llrrrr}
\hline & & mean & sd & p25 & p75 \\
\hline Pre Covid-19 & beta & 0.37 & 0.57 & 0.009 & 0.615 \\
& RE beta & 0.20 & 0.42 & -0.065 & 0.475 \\
& Covid-19 beta & -0.05 & 0.87 & -0.483 & 0.365 \\
& alpha & 0.000 & 0.002 & -0.001 & 0.001 \\
\hline Covid-19 & beta & 0.80 & 0.64 & 0.247 & 1.319 \\
& RE beta & 0.28 & 0.36 & 0.027 & 0.529 \\
& Covid-19 beta & 0.59 & 0.52 & 0.217 & 0.931 \\
& alpha & 0.000 & 0.005 & -0.003 & 0.003 \\
\hline
\end{tabular}


Note: The pre-Covid-19 period ranges from 21 November 2019 until 20 February 2020. The Covid-19 period ranges from 21 February 2020 until 21 April 2020. Beta and alpha are the coefficients associated with Equation (1). Covid-19 beta is the coefficient associated with Covid-19 risk factor.

The average cross-sectional market beta, or just beta thereafter, is 0.37 before the pandemic and goes up to 0.8 in the early stages of the pandemic. While the standard deviation remains similar, we see a change in the distribution in the tails as evidenced from the values of the $25^{\text {th }}$ and $75^{\text {th }}$ percentiles and the box-and-whisker plot in Figure 4.

Figure 4: Box and Whisker plots of the coefficients in the factor models before and during the pandemic outbreak
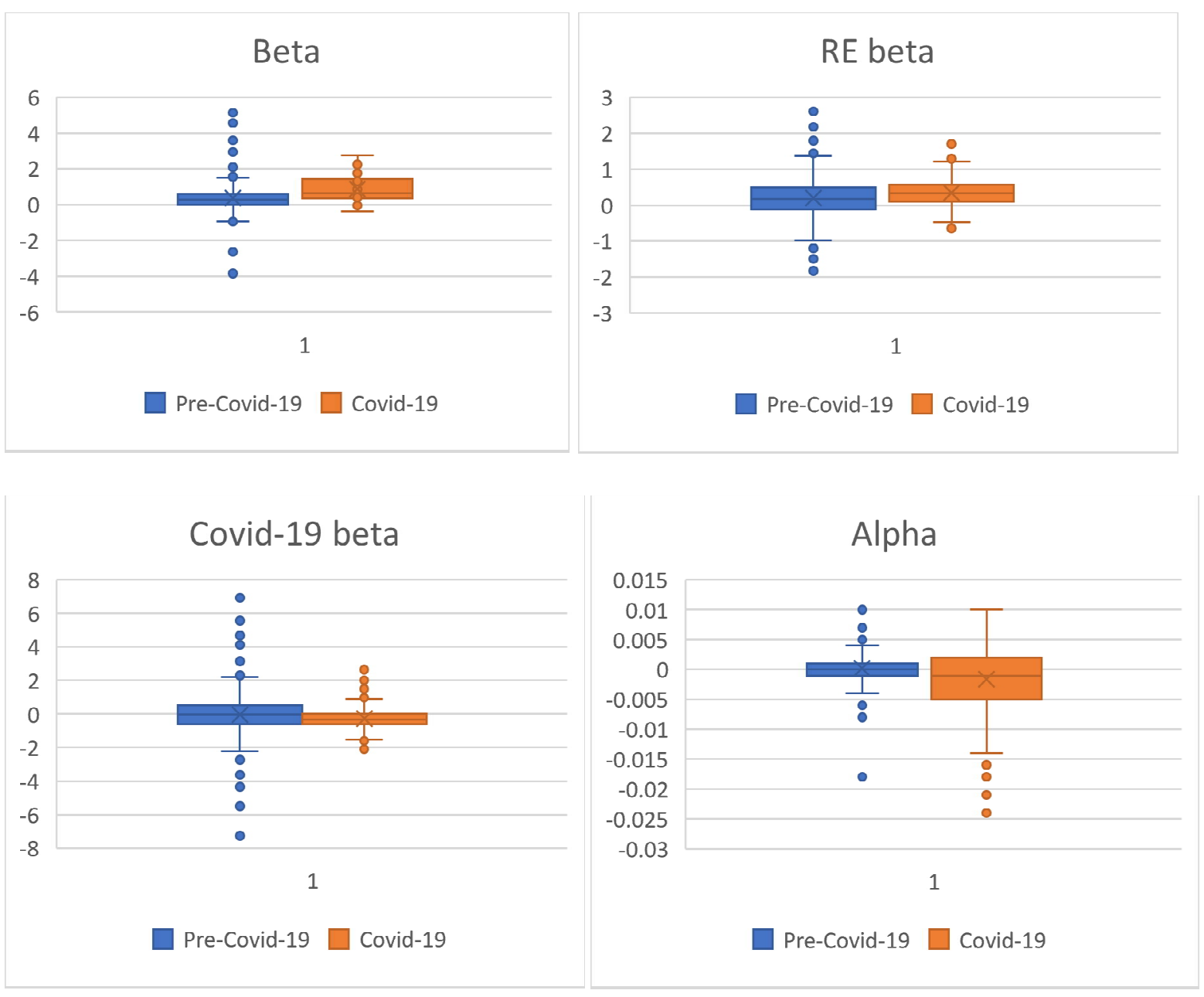
Note: The box-and-whisker plot shows the minimum, first quartile, median, third quartile, and maximum of our data. The coefficients are estimated using the factor model in Equation (1) for two periods using listed real estate companies in China, Hong Kong, Japan, Singapore, Sweden, Taiwan, US. The pre-Covid-19 period is from 21 November 2019 until 20 February 2020. The Covid-19 period is from 21 February 2020 until 21 April 2020.

The distribution has shifted to the right during the Covid-19 period, meaning that betas have increased for most companies. The bottom $25^{\text {th }}$ percentile of the distribution has a beta of 0.25 as compared to a beta of zero prior to the pandemic. The top $25^{\text {th }}$ percentile of the distribution has an average beta of 1.3 which is more than twice as high as the pre-Covid-19 beta of 0.6 . While the majority of the real estate companies had low stock market sensitivity prior to the virus outbreak, that sensitivity has increased twofold. Real estate firms at the top of the distribution are now reacting stronger than the market. While real estate is considered in general less volatile than the market, it is apparent that during highly volatile periods (as was the case during the GFC) real estate becomes more risky than the market itself. The high sensitivity to the market may be due to some real estate companies specialising on sectors which are proportionally harder affected by the lockdown measures as a result of the pandemic emerging.

The average real estate (RE) beta only goes up from 0.2 before Covid-19 to 0.28 thereafter. However, the distribution of RE betas shifts towards the right but becomes skewed. The bottom $25^{\text {th }}$ percentile of the distribution has a negative beta of -0.07 prior to the pandemic. The beta goes up to 0.03 . On the upper end of the distribution there are no large changes. This observation points towards a conversion in performance of real estate companies in response to changes on the real estate markets.

The largest increase in betas is observed for the Covid-19 beta which goes from nearly zero $(-0.05)$ prior to the pandemic to 0.6 during the outbreak. The close to zero average Covid-19 beta prior to the virus outbreak is in line with the assumption that before Covid-19, stocks should not be sensitive to the coronavirus-related risks. The sharp increase in the Covid-19 beta during the pandemic is associated with companies responding more strongly to increases in the growth rate of Covid-19 infections. About one fourth of the companies report a very high sensitivity to the Covid-19 risk factor of 0.93 . This is higher than the sensitives reported for the real estate factor. Looking at the bottom end of the distribution, even companies less sensitive to changes in virus infections would have a Covid-19 beta as high as the market beta. That means that the Covid-19 risk factor does a good job in capturing the risks associated with exposure to Covid-19 risks and real estate companies react more strongly to those risks than to real estate market risks. 
The cross-sectional alphas for both periods are on average around the zero mark. However, the distribution during the pandemic is much wider that prior to it prompting to some fat tails. The top $25^{\text {th }}$ percentile of the companies have an average alpha of 0.003 during the pandemic as compared to 0.001 prior to it. The same is observed at the bottom $25^{\text {th }}$ percentile.

While the systematic risk sensitivities are associated with a tighter distribution, the opposite is the case for non-market returns. The gap between firms that outperform and firms that underperform has increased as a result of the pandemic.

\subsection{Fama MacBeth regressions}

I move on to the discussion of the second stage of the estimations - the cross-sectional models. Table 6 shows the baseline Fama-M acBeth regressions for two sub-periods - for the per-Covid-19 period and for the Covid-19 period. The betas are calculated in the previous step using Equation (1). I include the idiosyncratic volatility following Ang et al. (2009). It measures how past firm idiosyncratic volatility can explain returns as it has previously been shown that this effect is significant is some cases. Past idiosyncratic volatility is the standard deviation of the residual of a factor model on the MSCI World and the FTSE EPRA/NAREIT global index returns for a period of one month prior to the respective sample period. This follows the calculation in Ang et al. (2009).

In addition, I control for a number of other drivers of returns using company-specific financial information. This includes controls for size effects using total asset capitalisation, leverage constraints using the debt-to-asset ratio, valuation effects using the price-to-book ratio, profitability effects using the return on average assets. I also include a dummy that captures whether the real estate company has a REIT status. All regressions are conducted with sector and country fixed effects and standard errors are clustered by firm.

The primary focus is on the cross-sectional relationship between risk - both systematic and idiosyncratic - and return. Table 6 shows the results. The dependence between average returns across firms and market betas is significantly negative in both periods. However, the relationship is more than three-times stronger during the coronavirus outbreak. While one would expect an upward sloping security market line (SML) - a positive relationship between returns and risks (beta) - the opposite is the case. Real estate companies with less market exposure perform better. This has been observed in past research as documented earlier in the paper. This negative relationship is strengthened during the pandemic meaning that the so called low-risk effect becomes stronger. The low-risk effect is the observation that stocks with low risk have high returns. Having high beta is not 
just bad during good times but it is particularly bad during bad times as in addition to the betas being higher, the loadings on the betas are also several times higher.

Having higher exposure to the real estate market is not associated with better or worse performance during normal times. During the coronavirus outbreak, the RE beta has a negative effect on returns providing supporting evidence for a low-risk effect stemming from the real estate market as well.

The most important coefficient in these regressions is that of the Covid-19 beta. For both periods, the Covid-19 beta has a significantly negative effect on returns. The effect is more than five times stronger during the pandemic. This finding suggests that returns are well explained by their exposure to the coronavirus risk in addition to other systematic risks. The higher the exposure to the systemic risk, the lower the return of a firm would be.

Prior to the outbreak, cross-sectional returns do not seem to be driven by firm-specific financials apart from firm size. However, during the pandemic, the leverage ratio, valuation ratio and profitability all matter for the cross-section of returns. The higher the debt ratio of a firm, the lower its average return would be during the pandemic. Similarly, firms with higher market valuation and higher return on assets perform better. Having a REIT status is associated with higher returns. These results suggest that investors look at firm-level fundamentals when deciding how to invest across stocks mostly during volatile periods.

Table 6: Baseline Fama M acBeth regressions before and during Covid-19 outbreak

\begin{tabular}{lrr}
\hline & $\begin{array}{r}\text { Model 1 } \\
\text { return Pre-Covid- } \\
\text { 19 }\end{array}$ & $\begin{array}{r}\text { Model 2 } \\
\text { return Covid- } \\
\mathbf{1 9}\end{array}$ \\
\hline Past idiosync. risk & $0.0372^{*}$ & -0.0675 \\
& -0.0203 & -0.0508 \\
beta & $-0.0018^{* * *}$ & $-0.0063^{* * *}$ \\
& -0.0004 & -0.0009 \\
RE beta & 0.0003 & $-0.0073^{* * *}$ \\
& -0.0006 & -0.0011 \\
Covid-19 beta & $-0.0006^{* *}$ & $-0.0043^{* * *}$ \\
& -0.0003 & -0.0005 \\
TotalAssets_In & $0.0002 * *$ & $0.0003^{*}$ \\
& -0.0001 & -0.0002 \\
DtA & -0.0012 & $-0.0038^{*}$ \\
& -0.0011 & -0.002 \\
PtB & 0 & $0.0008^{* *}$ \\
& -0.0001 & -0.0003 \\
ROAA & 0.0055 & $0.0166^{* *}$
\end{tabular}




\begin{tabular}{lrr} 
& -0.006 & -0.0066 \\
REIT status & 0.0002 & $0.0023^{* * *}$ \\
& -0.0003 & -0.0008 \\
Intercept & -0.0008 & $-0.0076^{* *}$ \\
& -0.0017 & -0.0031 \\
R-squared & 0.49 & 0.751 \\
$\mathrm{~N}$ & 382 & 382 \\
\hline
\end{tabular}

Note: DtA stays for the debt-to-assets ratio. PtB stays for the price-to-book ratio. ROAA stays for the return on assets ratio, REIT is a dummy that takes 1 if the company has a real estate investment trust status. Betas are estimated using a the factor model in equation (1) including the MSCI World (beta), FTSE EPRA/NAREIT global index (RE beta) and a Covid-19 Risk Factor (Covid-19 beta). The latter is estimated by sorting stocks into five portfolios based on their exposure to the daily growth rate of new confirmed Covid-19 cases. Past idiosync. risk is the standard deviation of the residual of a factor model on the M SCI World and the FTSE EPRA/NAREIT global index returns for the month preceding these models respectively. It measures how past firm idiosyncratic volatility can explain returns. All regressions are conducted with sector and country fixed effects and standard errors are clustered by firm. Standard errors are reported under each coefficient. ***,**,* stay for $1 \%, 5 \%$ and $10 \%$ significance levels respectively.

I see strong cross-sectional differences in daily returns based on the sector specialisation of the company. The strongest and most robust results are observed for real estate firms that specialise in industrial properties, which are associated with higher returns compared to firms which focus on offices (see Table 7). On the contrary, firms with a focus on shopping centers (or other types of retail) have significantly lower returns than companies focussing on offices. These results for industrial and shopping centers are highly robust to different specifications and point to strong divergence in sectorlevel performance during the pandemic. It is worth noting that those effects were present prior to the pandemic too but the gap has widened as a result of Covid-19. As demonstrated in Ling et al. (2020), sector specialisation in real estate holdings does play an important role for company performance.

\section{Table 7: Sector fixed effects}

\begin{tabular}{rrr}
\hline & $\begin{array}{r}\text { Model 1 } \\
\text { Pre-Covid-19 }\end{array}$ & $\begin{array}{r}\text { Model 2 } \\
\text { Covid-19 }\end{array}$ \\
\hline Casino & $0.0011^{* * *}$ & $0.0026^{* *}$ \\
& -0.0004 & -0.0011
\end{tabular}




\begin{tabular}{|c|c|c|}
\hline \multirow[t]{2}{*}{ Diversified } & $-0.0005^{*}$ & 0.0002 \\
\hline & -0.0003 & -0.0006 \\
\hline \multirow[t]{2}{*}{ Health Care } & 0.0001 & $0.0025^{* * *}$ \\
\hline & -0.0004 & -0.0008 \\
\hline \multirow[t]{2}{*}{ Hotel } & $-0.0018 * * *$ & $-0.0018 *$ \\
\hline & -0.0004 & -0.001 \\
\hline \multirow[t]{2}{*}{ Industrial } & $0.0008^{*}$ & $0.0019 * * *$ \\
\hline & -0.0004 & -0.0007 \\
\hline \multirow[t]{2}{*}{ Manufactured Home } & 0.0002 & 0.0019 \\
\hline & -0.0004 & -0.0012 \\
\hline \multirow[t]{2}{*}{ Multifamily } & -0.0003 & 0.0012 \\
\hline & -0.0003 & -0.0008 \\
\hline \multirow[t]{2}{*}{ Other Retail } & -0.0006 & 0.0011 \\
\hline & -0.0004 & -0.0013 \\
\hline \multirow[t]{2}{*}{ Regional Mall } & $-0.0018^{* *}$ & $-0.0042 * * *$ \\
\hline & -0.0007 & -0.0014 \\
\hline \multirow[t]{2}{*}{ Self-Storage } & $-0.0016 * * *$ & 0.0016 \\
\hline & -0.0005 & -0.0011 \\
\hline \multirow[t]{2}{*}{ Shopping Center } & $-0.0019 * * *$ & $-0.0033 * * *$ \\
\hline & -0.0004 & -0.0009 \\
\hline \multirow[t]{2}{*}{ Specialty } & 0 & $0.0032 * * *$ \\
\hline & -0.0005 & -0.001 \\
\hline
\end{tabular}

Note: The results are a continuation of the results in Table 6 , see note of Table 6 . The dependent variable is daily returns. Standard errors are reported under each coefficient. $* * *, * *, *$ stay for $1 \%, 5 \%$ and $10 \%$ significance levels respectively.

The international sample of firms and the choice of countries which have had previous exposure to coronaviruses and have more robust practices in place to respond to a pandemic allows to control for past experience with pandemics and the effects on stock markets. In the early stages of the pandemic, those countries may be perceived to be better equipped to cope with Covid-19 and hence may not be as negatively affected by the Covid-19 shock. In order to test for this assumption, I have included 
country fixed effects and present the results in Table 8. Above assumption seems to be confirmed by the results. During the pandemic, some countries perform significantly better than others. As China was the first to close down the majority of the economy, it was also the first to recover from the first wave of the virus. It eased down restrictions starting from $17 \mathrm{M}$ arch 2020. Singapore, in turn, did not close its economy in the early stages of the pandemic, therefore, the economic outlook might have been more positive for this country at that moment in time. Chinese and Singaporean firms have significantly higher returns as compared to US firms. ${ }^{8}$ These results are in line with the findings in Ru et al. (2020). Chinese and Hong Kong firms prior to the outbreak are associated with significantly lower returns than US firms. Countries with prior coronavirus experience are shown to have significantly higher returns. But those returns can also be due to other country specific time-constant factors and we cannot disentangle those. In fact, the results tend to vary depending on the factor choice in Equation (1) and therefore need to be interpreted with some caution.

\section{Table 8: Country fixed effects}

\begin{tabular}{lrr}
\hline & $\begin{array}{r}\text { Model 1 } \\
\text { return Pre-Covid- } \\
\mathbf{1 9}\end{array}$ & $\begin{array}{r}\text { Model 2 } \\
\text { return Covid- } \\
\mathbf{1 9}\end{array}$ \\
\hline China & $-0.0016^{*}$ & $0.0043^{* *}$ \\
Hong Kong & -0.0009 & -0.0021 \\
& $-0.0023^{* * *}$ & 0.0025 \\
Japan & -0.0006 & -0.0015 \\
& -0.0007 & -0.0009 \\
Singapore & -0.0005 & -0.0014 \\
& -0.0007 & $0.0031^{* * *}$ \\
Sweden & -0.0004 & -0.0012 \\
& 0.0007 & -0.0011 \\
& -0.0007 & -0.0014 \\
\hline
\end{tabular}

Note: The results are a continuation of the results in Table 6 , see note of Table 6 . The dependent variable is daily returns. Standard errors are reported under each coefficient. ***,**,* stay for $1 \%, 5 \%$ and $10 \%$ significance levels respectively.

Overall, during the early stages of the Covid-19 outbreak, real estate stocks are associated with a strong low-risk effect stemming from systematic risks and mostly from Covid-19 related risks. Part of the cross-sectional variation in returns is explained by sector and regional effects in addition to firm-

\footnotetext{
${ }^{8}$ In a modified specification I also see that Hong Kong also reports significantly higher returns.
} 
level fundamentals and thus sectoral and regional diversification can be beneficial in periods of high global systemic risks like the one experienced during Covid-19.

\subsection{Reasons for the low-risk effect}

Now I turn to assessing what may be behind the strong low-risk effects observed in both periods and how the negative signs in front of the beta risks can be explained. The reason for the low-risk effect can be associated with either (1) leverage constraints or (2) behavioural drivers as argued by Asness et al. (2020). Behavioural considerations normally go along with significant past idiosyncratic volatility. For example, Baker et al. (2007) link idiosyncratic volatility to differences in opinions. In our case, the effect of past idiosyncratic risk in the early stages of Covid-19 is insignificant, as seen in Table 9. This result suggests that behavioural effects may not be at play in the case of real estate companies. This result is robust to different specifications. During the period preceding the pandemic, past idiosyncratic volatility has a positive effect on returns meaning that stocks with high idiosyncratic risk are associated with high return and vice versa. The positive effect may be reflective of "broad, not easily diversifiable, factors", as suggested by Ang et al. (2009), who, however, find the opposite relationship for general stocks. Another reason for the significance of idiosyncratic risk may be associated with illiquidity as argued by Spiegel and Wang (2005). However, while this would be interesting to explore further, my focus is on the pandemic period and its comparison with the period prior to the coronavirus outbreak, therefore, this is left for future research.

Given that behavioural considerations are not explaining the low-risk effect during the pandemic, I turn to analyse to what extent financial constraints, as measured by the debt-to-asset (leverage) ratio, can be linked to the low-risk effect. I interact the market beta and the Covid-19 beta in each period with the leverage ratio of the company. The interaction terms can be seen as the moderator effect of the leverage ratio, which in Table 6 is significantly negative during the Covid-19 period. Interacting the betas with the leverage ratio will provide insights as to whether the low-risk effect exists because firms with low beta have low leverage and hence higher returns.

Table 9: Low-risk effect and financial constraints

\begin{tabular}{rrr}
\hline & Model 1 & Model 2 \\
& return Pre-Covid- & return Covid- \\
& $\mathbf{1 9}$ & $\mathbf{1 9}$ \\
\hline Past idiosync. risk & $0.0808^{* * *}$ & -0.0798 \\
& -0.0248 & -0.0514
\end{tabular}




\begin{tabular}{lrr} 
beta & 0.0007 & $-0.0026 * *$ \\
beta*DtA & -0.0005 & 0.0012 \\
& $-0.0050 * * *$ & $-0.0084 * * *$ \\
RE beta & -0.0011 & -0.0022 \\
& 0.0005 & $-0.0071^{* * *}$ \\
Covid-19 beta & -0.0005 & -0.0011 \\
& $0.0004^{* *}$ & -0.0002 \\
Covid-19 beta*DtA & -0.0002 & 0.0016 \\
& $-0.0022 * * *$ & $-0.0085^{* *}$ \\
DtA & -0.0005 & -0.0037 \\
& 0.0007 & $0.007 * *$ \\
Intercept & -0.001 & 0.0028 \\
& -0.0013 & $-0.0106 * * *$ \\
R-squared & -0.0013 & -0.0028 \\
$\mathrm{~N}$ & 0.581 & 0.771 \\
\hline
\end{tabular}

Note: DtA stays for the debt-to-assets ratio. Past idiosync. risk is the standard deviation of the residual of a factor model on the MSCI World and the FTSE EPRA/NAREIT global index returns for the preceding these models respectively. It measures how past firm idiosyncratic volatility can explain returns. Betas are estimated using the factor model specified in equation (1) including the M SCI World (beta), FTSE EPRA/NAREIT global index (RE beta) and a Covid-19 Risk Factor (Covid-19 beta). The latter is estimated by sorting stocks into five portfolios based on their exposure to the daily growth rate of new confirmed Covid-19 cases. All regressions are conducted with sector and country fixed effects and standard errors are clustered by firm. I include the same controls as in Table 6 but do not report them for brevity. Standard errors are reported under each coefficient. ***, **,* stay for $1 \%$, $5 \%$ and $10 \%$ significance levels respectively.

The results are reported in Table 9. During the pandemic, some low-risk effect associated with systematic risks of the stock market is observed that cannot be explained by the leverage ratio. However, the interaction terms are significantly negative while the Covid-19 beta turns insignificant and the debt-to-asset ratio becomes significantly positive during the Covid-19 period. The low-risk effect associated with Covid-19 exposure can be explained with financial constraints. The negative significance of the Covid-19 beta disappears once we interact it with financial constraints. That suggests, that while higher leverage ratio is associated with higher returns (positive DtA coefficient), leverage has a moderating (negative) effect on returns through the exposure to Covid-19 risks. Companies with the same exposure to Covid-19 risks would perform worse the higher their leverage is (negative interaction term). Covid-19 exposure alone would not have a significant effect once we interact it with leverage. This finding suggests that the Covid-19 low risk effect propagates through financial constraints. 
These results are in line with several recent papers which examine the effect of corporate characteristics on stock returns during the pandemic. Ramelli and Wagner (2020) and Alfaro et al. (2020) find that more leveraged firms severely suffer during the peak of the pandemic. Similarly, Fahlenbrach et al. (2020) show that firms with less financial flexibility experience lower equity returns up until the QE announcement of the Fed. Ding et al. (2020) report that firms with less debt, more cash and larger profits are associated with lower stock returns. Similarly to the existing research on the effects of Covid-19 on stock markets, the findings in this paper suggest that investors perceived the shock caused by the pandemic to be amplified by financial channels.

\subsection{Robustness Tests}

Instead of using the stock market factors and the real estate factor, I estimate all models including the construction of the factor using the three Fama and French (FF) factors instead. The results are reported in Tables A1 and A2 in the Appendix. Table A1 shows the baseline results and is equivalent to Table 6 . Whereas Table A2 shows the channels of the risk effect and is comparable to Table 9. Overall, the key results remain robust. We see a significant risk effect for all risk factors during Covid19 (see Table A1), similar to Table 6. Table A2 confirms that the low-risk effect associated with Covid19 stems from financial constraints and is not associated with behaviour biases.

Furthermore, in addition to using a Covid-19 risk factor, we estimate the factor models in Equation (1) directly using Covid-19 cases data. In one of the robustness we use the daily change in confirmed cases as the measure for exposure to infection. In another specification we use the natural logarithm of the Covid-19 cases. The results remain robust.

\section{Conclusion}

This paper examines the presence of a low-risk effect for real estate companies and its channels before and during the Covid-19 outbreak. This study contributes to the literature in various ways. It is among the very first ones to study the low-risk effect for real estate firms. A further contribution is the construction of a Covid-19 Risk Factor to assess the sensitivity of individual firms to Covid-19 risks. The risk factor is linked to daily changes in confirmed global Covid-19 cases and is not correlated with other stock market factors. The study then looks at how Covid-19 risks affect the cross-section of returns in addition to other systematic and idiosyncratic risks. Following on from the recent research by Ling et al. (2020) on the effects of Covid-19 on REIT returns, it is also among the first to assess asset pricing behaviour as a result of Covid-19 internationally. 
There are a number of findings. First, I show that the co-movement of real estate firms with the stock market strongly increases during the early periods of the Covid-19 outbreak. This is indicative of reduced diversification benefits of listed real estate during volatile periods. Second, real estate companies show evidence for a low risk effect which cannot be explain by behavioural biases. Third, firms with high exposure to Covid-19 have been associated with steep declines in average daily returns. This effect is mostly explained by leverage constraints. Firms with the same Covid-19 exposure would have lower returns if their leverage is higher. Fourth, the average firm sensitivity to the Covid19 risk factor increases from close to zero prior to the pandemic to 0.6 during the pandemic. There are large cross-sectional differences in performance across countries and property sectors. Real estate sectors such as retail have the highest sensitivity to Covid-19 risks of 1.2 during the pandemic while health care has the lowest sensitivity of 0.25 . The effect of the pandemic on sectors has been associated with widening the gap between the performance across sectors. Overall, in line with the existing research on the effects of Covid-19 on stock markets, the findings in this paper suggest that investors perceived the shock caused by Covid-19 to be amplified by financial channels. 


\section{References}

Alfaro, L., Chari, A., Greenland, A. N., and Schott, P. K., 2020, Aggregate and firm-level stock returns during pandemics, in real time, Harvard Business Review Working Paper, No. 26950.

Ang, A., Hodrick, R. J., Xing, Y., Zhang, X., 2009. High idiosyncratic volatility and low returns: international and further US evidence. Journal of Financial Economics 91 (1), 1-23.

Ang, A., Hodrick, R.J., Xing, Y., Zhang, X., 2006. The cross-section of volatility and expected returns. Journal of Finance 51, 259-299.

Asness, C., Frazzini, A., Cormsen, N. J., and Pedersen, L. H., 2020. Betting against correlation: Testing theories of the low-risk effect. Journal of Financial Economics 135, 629-652.

Asness, C. S., Frazzini, A., Pedersen, L.H., 2014. Low-risk investing without industry bets. Financial Analysts Journal 70 (4), 24-41.

Baker, M., Bradley, B., Wurgler, J., 2011. Benchmarks as limits to arbitrage: understanding the low volatility anomaly. Financial Analysts J ournal 67 (1), 40-54.

Baker, M., Coval, J., Stein, J.C., 2007. Corporate financing decisions when investors take the path of least resistance. Journal of Financial Economics 84, 266-298.

Bali, T., Brown, B., Murray, S., Tang, Y., 2014. Betting against beta or de-mand for lottery. Unpublished working paper. Georgetown University.

Bali, T. G., Bodnaruk, A., Scherbina, A., and Tang, Y., 2018. Unusual News Flow and the Cross Section of Stock Returns. M anagement Science 64(9):4137-4155. https:// doi.org/10.1287/mnsc.2017.2726

Bali, T.G., Brown, S., M urray, S., Tang, Y., 2017. A lottery demand-based explanation of the beta anomaly. J. Financ. Quant. Anal. 52 (6), 2369-2397.

Bali, T.G., Cakici, N., Whitelaw, R.F., 2011. Maxing out: stocks as lotteries and the cross-section of expected returns. Journal of Financial Economics, 99 (2), 427-446.

Barberis, N., Huang, M., 2008. Stocks as lotteries: the implications of probability weighting for security prices. American Economic Review 98 (5), 2066-2100.

Black, F., 1972. Capital market equilibrium with restricted borrowing. Journal of Business 45, 444-455.

Black, F., Jensen, M., Scholes, M.S., 1972. The capital asset pricing model: some empirical tests. In: Jensen, M. (Ed.), Studies in the Theory of Capital M arkets, Praeger, New York, 79-121.

Brennan, M., Subrahmanyam, A., 1995. Investment analysis and price formation in securities markets. Journal of Financial Econometrics 38, 361-381.

Brunnermeier, M. K., Gollier, C., Parker, J. A., 2007. Optimal beliefs, asset prices, and the preference for skewed returns. American Economic Review 97 (2), 159-165.

Cohen, R.B., Polk, C., Vuolteenaho, T., 2005. Money illusion in the stock market: the M odigliani-Cohn hypothesis. The Quarterly Journal of Economics, 120 (2), 639-668. 
Ding, W., Levine, R. Lin, C., and Xie, W., 2020. Corporate immunity to the COVID-19 pandemic, Working Paper.

Fahlenbrach, R., Rageth, K, and Stulz, R. M., 2020. How valuable is financial flexibility when revenue stops? Evidence from the COVID-19 crisis, Swiss Finance Institute Research Paper No. 20-37.

Fama, E. F., French, K. R., 1992. The cross-section of expected stock returns. Journal of Finance 47, 427-465.

Fama, E. F., French, K. R., 1993. Common risk factors in the returns on stocks and bonds. Journal of Financial Economics 33, 3-56.

Frazzini, A., Pedersen, L. H., 2014. Betting against beta. Journal of Financial Economics 111, 1-25.

Gormsen, N. J., and Koijen, R. S. J., 2020. Coronavirus: Impact on Stock Prices and Growth Expectations, Working Paper.

Harvey, C. R., 1989. Forecasts of Economic Growth from the Bond and Stock Markets. Financial Analysts Journal, 45 (5), 38-45.

Hong, H., Sraer, D. A., 2016. Speculative betas. Journal of Finance 71 (5), 2095-2144.

Li, F. W., 2016. Macro Disagreement and the Cross-Section of Stock Returns, The Review of Asset Pricing Studies, 6:1, June 2016, 1-45.

Ling D., Wang, C. and Zhou, T., 2020. A first look at the impact of Covid19 on commercial real estate prices: Asset-level evidence. SSRN Working Paper.

Modigliani, F., Cohn, R., 1979. Inflation, rational valuation, and the market. Financial Analysts Journal, 35 (3), 24-44.

OECD, 2020. OECD Economic Outlook, June 2020.

Rachwalski, M. and Wen, Q., 2016. Idiosyncratic Risk Innovations and the Idiosyncratic Risk-Return Relation, The Review of Asset Pricing Studies, 6:2, December 2016, 303-328.

Ramelli, S. and Wagner, A. F., 2020. Feverish Stock Price Reactions to COVID-19, The Review of Corporate Financial Studies, published online July $7^{\text {th }} 2020$.

Ru, H., Yang, E., and Zou, K., 2020. Combating the COVID-19 Pandemic: The Role of the SARS Imprint, SSRN Working Paper.

Shen, J., Yu, J., 2012. Investor sentiment and economic forces. Unpublished working paper. University of M innesota.

Spiegel, M., Wang, X., 2005. Cross-sectional variation in stock returns: liquidity and idiosyncratic risk. Unpublished working paper, Yale University.

Wang, H, Yan, J. and Yu, J., 2017. Reference-dependent preferences and the risk-return trade-off. Journal of Financial Economics 123, 295-414. 


\section{Appendix}

Table A1: Baseline model using the FF factors in the first step instead

\begin{tabular}{lrr}
\hline & return Pre & $\begin{array}{r}\text { return } \\
\text { Covid19 }\end{array}$ \\
\hline Past idiosync. risk (FF) & 0.0001 & -0.0543 \\
& -0.0169 & -0.0533 \\
Beta (M kt-RF) & $-0.1898^{* * *}$ & $-0.5327 * * *$ \\
& -0.0572 & -0.1224 \\
Beta (SM B) & -0.0152 & $-0.0813^{* * *}$ \\
& -0.045 & -0.0273 \\
Beta (HML) & -0.0759 & $-0.5033^{* * *}$ \\
& -0.0466 & -0.0463 \\
Covid-19 beta (FF) & $-0.0005^{*}$ & $-0.0054 * *$ \\
& -0.0003 & -0.0008 \\
R-squared & 0.436 & 0.754 \\
N & 383 & 384 \\
\hline
\end{tabular}

Note: DtA stays for the debt-to-assets ratio. PtB stays for the price-to-book ratio. ROAA stays for the return on assets ratio, REIT is a dummy that takes 1 if the company has a real estate investment trust status. Beta (M ktRF) stays for the betas of the FF market factor from equation (1); beta (SM B) stays for the betas of the FF size factor from equation (1); beta (HML) stays for the betas from of the FF value factor from equation (1). Covid-19 beta (FF) stays for the beta of the Covid-19 Risk Factor using the FF Factors instead. Past idiosync. Risk (FF) is the standard deviation of the residual of a factor model on the three FF factors for the preceding month of the models presented here. It measures how past idiosyncratic volatility can explain future returns. All regressions are conducted using the same variables as in Table 6 including sector and country fixed effects and standard errors are clustered by firm. Those results are not reported for brevity but are available upon request. Standard errors are reported under each coefficient. $* * *, * *, *$ stay for $1 \%, 5 \%$ and $10 \%$ significance levels respectively.

Table A2: Low-risk effect and financial constraints using FF factors

\begin{tabular}{lrr}
\hline & Return Pre & $\begin{array}{r}\text { Return } \\
\text { Covid19 }\end{array}$ \\
\hline Past idiosync. risk (FF) & 0.0037 & -0.0538 \\
& -0.0143 & -0.0512 \\
DtA & 0.0012 & 0.0028 \\
& -0.0011 & 0.0032 \\
Beta (M kt-RF) & $0.1684^{*}$ & $-0.5449^{* *}$ \\
Beta (M kt-RF)*DtA & -0.086 & -0.23 \\
& $-0.7227 * * *$ & -0.0433 \\
Beta (SM B) & -0.1973 & -0.4282 \\
& -0.1293 & -0.0805
\end{tabular}




\begin{tabular}{lrr} 
& -0.0936 & -0.09 \\
Beta (SM B)*DtA & 0.2405 & 0.0305 \\
& -0.176 & -0.1747 \\
Beta (HML) & -0.131 & $-0.3775^{* * *}$ \\
& -0.0983 & -0.1297 \\
Beta (HM L)*DtA & 0.1222 & -0.2525 \\
& -0.233 & -0.2495 \\
Covid-19 beta & -0.0001 & -0.0014 \\
& -0.0004 & -0.0015 \\
Covid-19 beta*DtA & -0.0008 & $-0.0085 * * *$ \\
& -0.0009 & -0.0031 \\
R-squared & 0.486 & 0.761 \\
$\mathrm{~N}$ & 383 & 384 \\
\hline
\end{tabular}

Note: DtA stays for the debt-to-assets ratio. PtB stays for the price-to-book ratio. ROAA stays for the return on assets ratio, REIT is a dummy that takes 1 if the company has a real estate investment trust status. Beta (M ktRF) stays for the betas of the FF market factor from equation (1); beta (SM B) stays for the betas of the FF size factor from equation (1); beta (HML) stays for the betas from of the FF value factor from equation (1). Covid-19 beta (FF) stays for the beta of the Covid-19 Risk Factor using the FF Factors instead. Past idiosync. Risk (FF) is the standard deviation of the residual of a factor model on the three $\mathrm{FF}$ factors for the preceding month of the models presented here. It measures how past idiosyncratic volatility can explain future returns. All regressions are conducted using the same variables as in Table 6 including sector and country fixed effects and standard errors are clustered by firm. Those results are not reported for brevity but are available upon request. Standard errors are reported under each coefficient. $* * *, * *, *$ stay for $1 \%, 5 \%$ and $10 \%$ significance levels respectively. 